EESTI NSV TEADUSTE AKADEEMIA TOIMETISED, 27. KOIDE KEEMIA, 1978, NR. 3

ИЗВЕСТИЯ АКАДЕМИИ НАУК ЭСТОНСКОИ ССР. ТОМ 27 ХИМИЯ. 1978, № 3

Евгения БОНДАРЬ, Р. ВЕСКИ, удК $662.67: 547.46: 547.58$ H. ФИЛИМОНОВА, А. ФОМИНА

\title{
ОБ АРОМАТИЧЕСКИХ СТРУКТУРАХ КЕРОГЕНА ДИКТИОНЕМОВОГО СЛАНЦА
}

\author{
Jevgenia BONDAR, R. VESKI, N. FILIMONOVA, A. FOMINA. DIKTOONEEMAKILDA KEROGEENI \\ AROMAATSEST STRUKTUURIST
}

Eugenia BONDAR, R. VESKI, N. FILIMONOVA, A. FOMINA. ABOUT AROMATIC STRUCTURES OF DICTYONEMA SHALE KEROGEN

В продуктах окисления диктионемового сланца перманганатом калия в щелочной среде методом распределительной хроматографии на силикагеле $\left[{ }^{1-3}\right]$ определены алифатические дикарбоновые кислоты, которые были установлены ранее в продуктах аналогичного окисления керогена кукерсита - сланца, образовавшегося, как и диктионемовый, в ордовикском периоде, но более молодого. Значительная доля кислотного гидроксила в промежуточных продуктах окисления диктионемового сланца, идентификация только алифатических кислот (за исключением бензойной, обнаруженной в следовых количествах [3]), а также наличие в продуктах гидролиза сахаров - все это позволило заключить, что в составе керогена диктионемового сланца содержатся оксиароматические и углеводные структуры. Сходство алифатической части керогенов диктионемового сланца и кукерсита отмечается при сравнении состава $\boldsymbol{H}$-парафинов и 1-олефинов, выделенных из смол их полукоксования [ $\left.{ }^{4}\right]$.

Хотя об ароматических структурах органического вещества диктионемового сланца упоминается во многих работах, однако доказательных исследований не имеется.

Газохроматографическим анализом метилированных диазометаном растворимых продуктов азотнокислого окисления диктионемового сланца Маардуского месторождения (хроматограф ЛХМ 8 МД, модель 5; в условиях программирования температуры; газ-носитель - гелий), наряду с алифатическими дикарбоновыми $\mathrm{C}_{4}-\mathrm{C}_{19}(\sim 63 \%)$ и монокарбоновыми $\mathrm{C}_{10}-\mathrm{C}_{25}(\sim 12 \%)$ кислотами, были идентифицированы следующие бензолкарбоновые кислоты: бензойная, ортофталевая, терефталевая, гемимеллитовая, тримезиновая, тримеллитовая, меллофановая, пиромеллитовая, пренитовая (предположительно), бензолпентакарбоновая и меллитовая. На хроматограмме (см. рисунок) цифры у пиков соответствуют числу углеродных атомов в молекуле моно- (не подчеркнуты) и дикарбоновых (подчеркнуты) кислот. Бензолкарбоновые кислоты обозначены условно с указанием местоположения карбоксильной группы. 
Хроматограммы эфирного экстракта растворимых продуктов окисления диктионемового сланца на полярной (I) и неполярной (II) неподвижных фазах. Колонки: (I) $-1,5 \%$ LAC2-R-446 на хромосорбе $W A W 80-100$ меш., длина 1 м, внутренний диаметр 3 мм; (II) $-1 \%$ апьезона $L$ на хромосорбе $W A W 60-80$ меш., длина $1 \mathcal{M}$, внутренний диаметр 3 м.M.

Для однозначной. идентификации бензолкарбоновых кислот были применены колонки с полярной ( I - LAC2-R-446) и неполярной (II - апьезон $L$ ) неподвижными фазами и индивидуальные бензолкарбоновые кислоты, из которых были приготовлены метиловые эфиры и их смеси. На колонке (I), разделяющей метиловые эфиры моно- и дикарбоновых кислот, метиловые эфиры изомеров бензолтрикарбоновых и бензолтетракарбоновых кислот не разделяются и выходят общими пиками. Не было достигнуто также

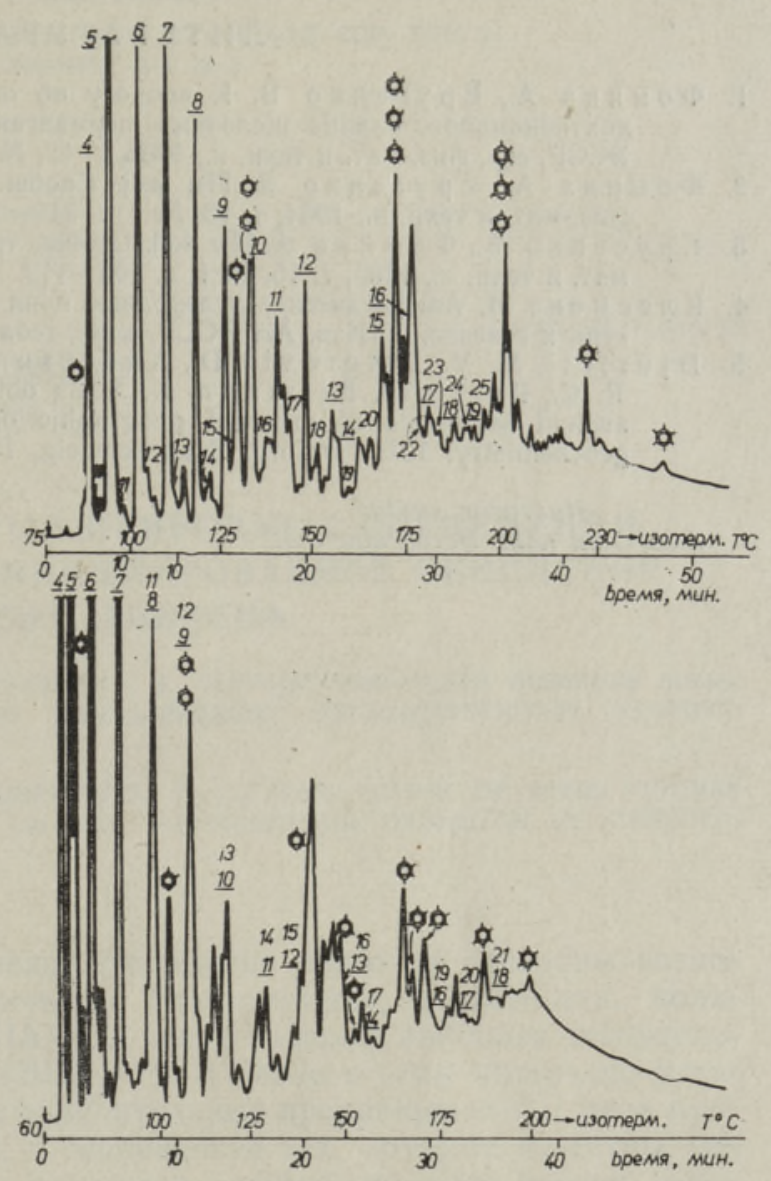
разделения метиловых эфиров орто- и изофталевой кислот. На колонке (II), не разделяющей метиловые эфиры моно- и дикарбоновых кислот, было достигнуто разделение метиловых эфиров изомеров бензолтрикарбоновых и бензолтетракарбонавых кислот, но метиловые эфиры азелаиновой, тере- и изофталевой кислот разделены не были.

Идентифицированные бензолкарбоновые кислоты составили около $14 \%$ от хроматографируемых кислот исследуемой пробы. Аналогичные продукты деструкции керогена кукерсита азотной кислотой и перманганатом калия в щелочной среде содержат ароматические кислоты в виде следов или они вообще не обнаруживаются.

В заметных количествах бензолкарбоновые кислоты идентифицированы в продуктах окислительной деструкции и других сланцев, например, алексинацких и киммериджских, а также австралийского торбанита [5].

Проведенное исследование указывает на существенное различие керогенов двух сланцев, образовавшихся из морских организмов ордовикского периода, т. е. в то время, когда практически еще отсутствовала наземная растительность.

Идентификацией бензолкарбоновых кислот прямым методом показана определенная роль ароматических структурных элементов в керогене диктионемового сланца, которые в условиях окисления азотной кислотой способны образовывать, очевидно, весь ряд бензолкарбоновых кислот. 


\section{Л И Т Е Р А Т У Р А}

1. Фомина А., Е р усенко диктионемового сланца щелочным перманганатом калия. I сообщ. - Изв. АН ЭССР, сер. физ.-мат. и техн. н., 1963, т. 12, № 2, с. $189-197$.

2. Фомин а А., Е у сенко В. [То же]. Сообщ. второе. - Изв. АН ЭССР, сер. физ.-мат. и техн. н., 1964 , т. 13, № 4, с. 319-328.

3. Е р у с ен ко В., Ф о мин а А. [То же]. Сообщ. третье. - Изв. АН ЭССР, сер. физ.мат. и техн. н., 1966 , т. 15, № 1, с. 106-112.

4. Клесм ент И. Алифатические углеродные цепи керогена горючих сланцев. Структура и генезис. - Изв. АН ЭССР, хим., геол., 1975, т. 24, № 2, с. 123-129.

5. D juricic, M. V., Vitorovic, D., Andreson, B. D., Hertz, H. S., Murphy, R. C., Preti, G., B i emann, K. Acids obtained by oxidation of kerogens of ancient sediments of different geographic origin. - In: Advances. in organic geochemistry, 1971. Oxford, Braunschweig, Pergamon Press, 1972, p. 305-321.

Ннститут химии

Академии наук Эстонской ССР
Поступила в редакцию 28/I 1977 